\title{
EL MODEL LÈXIC CULTE DE CONSTANTÍ LLOMBART
}

\author{
THE FORMAL LEXICAL MODEL \\ OF CONSTANTÍ LLOMBART
}

\author{
Joaquim Martí Mestre \\ Universitat de València \\ joaquin.marti@uv.es
}

Resum: En aquest article s'estudia el model lèxic culte de Constantí Llombart, un dels principals representants de la Renaixença valenciana. Llombart pretenia fer extensiu aquest moviment de recuperació cultural a tots els sectors de la societat valenciana i, per això, va assajar per a la llengua literària un model lingüístic de síntesi, que evitàs les formes considerades vulgars i castellanitzants de la llengua col-loquial, però també els arcaismes que poguessen distanciar-lo dels sectors populars. En la depuració lèxica de la llengua literària, Llombart tingué en compte els clàssics i els escriptors renaixentistes de Catalunya, on creia que el moviment de recuperació cultural estava més consolidat que a València, així com les fonts lexicogràfiques, especialment els diccionaris de Carles Ros i de Josep Escrig, i segurament també el de Labèrnia. Sense renunciar al lèxic popular i dialectal, es va proposar la recuperació literària de veus tradicionals, envellides o decadents, que rebien la competència de castellanismes, i va incorporar-hi neologismes i veus introduïdes en la llengua literària catalana durant el segle xix.

Paraules clau: història de la llengua catalana, història del lèxic català, llengua literària, Renaixença valenciana.

Abstract: Our aim in this contribution is to focus attention on the lexical model of Constantí Llombart, one of the main representatives of the Renaixença (19thC. Catalan Renaissance) in Valencia. Llombart wanted to extend this movement of cultural recovery to the whole of Valencian society. And that is why he proposed for literary language a linguistic model of synthesis, avoiding the vulgar forms and the Spanish forms of the colloquial language, but also the archaisms that could distance it from the popular sectors. In the lexical purity of the literary language, Llombart took into account the classical writers and the Catalan writers of the Renaixença, as 
JoAquim Martí Mestre

well as the lexicographic sources, especially the dictionaries of Carles Ros and Josep Escrig, and surely also that of Labèrnia. Without renouncing the popular and dialectal lexicon, he proposed the literary recovery of traditional words, which were unused or decadent, and that experienced the competence of Spanish forms, and he incorporated neologisms and words introduced in the literary Catalan language during the igth century.

Key words: History of the Catalan language, history of the Catalan lexicon, literary language, Valencian Renaixença.

coser es

\section{LA LLENGUA LITERÀRIA SEGONS LLOMBART}

Constantí Llombart pretenia implicar tothom en la tasca de recuperació de la llengua i la literatura pròpies, no sols els sectors cultes, sinó també els escriptors de vocació popular i el públic lector en general. Només així es podria aconseguir l'extensió i la implantació social de la Renaixença. Però aquesta era una labor complexa i progressiva, que requeria un temps per a poder completar-se. Per això, en un principi, tenint en compte l'escassa o nul.la familiarització de la major part dels lectors valencians amb un model lingüístic català culte, va tolerar que la literatura de vocació popular continuàs utilitzant el llenguatge al qual estaven acostumats els seus lectors, a través de la tradició dels col-loquis, dels sainets, de la premsa satírica i d'altres textos de caràcter jocós i festiu, i, de fet, ell mateix el va practicar en les seues obres de vocació popular.

Ara bé, en les produccions literàries de més volada, si hom volia que el català fos una llengua de cultura al País Valencià, calia fer servir el que Llombart anomenava «llemosí literari». Aquesta varietat, però, sense una tradició recent, requeria un esforç per part dels escriptors del moment, que havien de construir i difondre un model lingüístic culte amb el qual acabassen identificant-se tots els lectors potencials. Perquè l'objectiu final de Llombart era que, al cap d'uns anys, aquest model, assimilat per tothom, escriptors i lectors, acabàs essent utilitzat en totes les composicions literàries, de qualsevol gènere.

Aquesta llengua literària moderna, segons Llombart, havia de resultar d'una síntesi entre el llenguatge actual i el clàssic, evitant els barbarismes i els vulgarismes del primer i els arcaismes del segon. Havia de ser, per tant, un model integrador i selectiu, que tractàs de substituir castellanismes o formes considerades vulgars o poc literàries del «valencià que ara es parla» per altres de més cultes o genuïnes, sense perdre de vista la realitat lingüística del seu temps ni caure en una llengua arcaïtzant. Per suplir 
les formes enteses com a inapropiades, hom tenia en compte la tradició lingüística literària i les solucions dels escriptors renaixentistes d'altres territoris, sobretot del Principat, on, segons Llombart, el moviment renaixentista estava més consolidat, i on ja s'havia assentat el llenguatge literari culte.

Igualment, Llombart va tenir presents les fonts lexicogràfiques, especialment els diccionaris de Carles Ros i de Josep Escrig. ${ }^{1}$ El primer autor era vist per Llombart com l'iniciador de la restauració del valencià (F 32). Quant al Diccionario valencianocastellano (I85I) d'Escrig, el considerava la base de tots els diccionaris «que en lo sucesivo se redacten y publiquen» ( $E s c L l$, xIII), i ell mateix, a l'espera d'una obra més ambiciosa, se'n feu càrrec de la tercera edició, corregida i augmentada (I887-1895).

Prenent en consideració els principis que mantingué Llombart per a l'elaboració de la llengua literària, repassarem a continuació com es va concretar aquest model en el nivell lèxic, a través de l'anàlisi de la seua producció culta, en poesia, teatre i assaig. ${ }^{2}$ Veurem que no va ser un procés facil. Llombart, com els altres escriptors valencians contemporanis compromesos amb la restauració del català, s'enfrontaren a nombroses dificultats. D'una banda, calia comptar amb la forta pressió del castellà, única llengua que aleshores tenia una norma universalment reconeguda i era usada habitualment en tota classe de textos. De fet, ells mateixos tenien una formació castellana. Uns altres problemes eren, a més de la manca de suport institucional i d'implicació de la societat valenciana en conjunt, l'absència de models literaris cultes valencians recents, així com d'un diccionari fiable o d'estudis lingüístics que els ajudassen a superar els dubtes que sovint se'ls plantejaven.

\section{UN MODEL OBERT}

Llombart va anar introduint al llarg dels anys alguns canvis puntuals en el seu model de llengua literària culta. Aquestes variacions manifesten les inseguretats de

I. En la seua edició del diccionari d'Escrig $(E s c L l)$ cita diverses obres «que debieran consultarse para el estudio de nuestra lengua", on inclou diversos diccionaris, i Guardiola (2005) es refereix als diccionaris que influïren en $E s c L l$. No és descartable que en la seua producció literària culta tingués presents aquestes fonts, o almenys algunes d'elles. En aquest sentit, a més de Ros i d'Escrig, veiem bastant probable la consulta del diccionari de Labèrnia, referència dels escriptors renaixentistes catalans. Encara que ara no podem presentar un estudi exhaustiu d'aquest aspecte, vegeu especialment la nota 17.

2. Convé recordar que el projecte reformista de Llombart comprenia el conjunt de la llengua literària, no únicament el lèxic, sinó també l'ortografia i la gramàtica, i fins i tot es plantejava la creació d'una acadèmia de la llengua. Per a l'ortografia, la fonètica i la morfologia, vegeu Martí (2005).

Caplletra 69 (Tardor, 2020), p. 61-84 
JoAquim Martí Mestre

l'autor en la construcció de la llengua literària, però al mateix temps són indici d'una voluntat oberta a la revisió i a la millora constants. Era habitual, i comprensible en aquelles circumstàncies, que els escriptors renaixentistes tinguessen dubtes en les seues tries lingüístiques. Així ho manifestava Teodor Llorente en el seu Llibret de versos (I885): «QQuants ductes a cada rengló que s’escriu!»(Roca 2007: I69-I70). A conseqüència d'això no era estrany que introduïssen canvis lingüístics quan tenien l'oportunitat de reeditar les seues obres.

Podem observar amb facilitat aquestes modificacions si comparem les biografies editades en Lo Rat Penat. Calendari llemosi (I874-1883) (C) i en Los fills de la mortaviva $(\mathrm{F})$, obra que no es va acabar de publicar fins a l'any i883. Les diferències són més visibles en els textos dels primers anys, i afecten tots els nivells lingüístics.

Encara que molts canvis són purament estilístics, en les variacions lingüístiques, en general, en $\mathrm{F}$ s'observa, respecte a $\mathrm{C}$, una tendència a preferir solucions més pròximes a la varietat valenciana, així com una certa preferència per algunes formes més actuals i populars, sempre dins d'uns paràmetres literaris formals.

També Llorente, en reeditar els seus poemes en el Llibret de versos, eliminà o substituí «diccions arcaiques, que no tots comprenen» (Roca 2007: 97), i Cebrian Mezquita, poeta del cercle de Llombart, en la «carta-prólech» al llibre de Bodria Festes de carrer (València, I906), afirmava que «al voler crear lo modérn llenguatje valenciá lliterari», els poetes reunits en la casa de Llombart, "pesávem y medíem la conveniénsia [...] de’ncomensar per la ecsageració de la nóta arcáica, que ya’s devallaría més tart y póch á póch al punt de correcció que convinguera» (p. XIV). I en certa manera és comprensible que s'emmirallassen en la llengua clàssica, ${ }^{3} \mathrm{i}$ es veiessen temptats a seguir les formes antigues, si, com diu Llombart, es tractava de dignificar «la ajabacanada llengua llemosina» (F 3I2) i fer d'aquesta una «llengua erudita i culta» com «en temps pasats» (F I7), apta per als registres formals i elevats.

Després una major reflexió els permetria mesurar les formes excessivament arcaiques, i donar entrada a elements més actuals i familiars per a un lector valencià mitjà. En el cas de Llombart, si comparem les versions de $\mathrm{C}$ i de $\mathrm{F}$, hi ha una reducció considerable en l'ús dels pronoms adverbials en i hi, excessius i sovint mal usats en C. Així mateix, s'eliminen els pocs plurals en -as de C, com també el possessiu arcaic llur (i llurs), i molts casos del numeral dues, no sempre ben usat en C. També es nota la substitució dels imperfets de subjuntiu en $-s$ pels corresponents en $-r$, i de molts casos de l'article masculí $l o$, ja antiquats en el valencià de l'època, per la forma reforçada $e l o$ l'asil-làbica $l, o, d$ 'acord amb l'ús popular valencià, de vegades substitueix la preposició

3. Llombart animava els poetes valencians contemporanis a imitar els escriptors clàssics (E 23). 
$a b$ per la confusionària en, encara que no sempre. Igualment, tendeix a un major ús de $l l$-inicial en els cultismes. Entre les variants formals, canvia les antigues «aymador» (C I878, 109) per «amador» (F 333), «deembre» (C 1877, 26) per «decembre» (F 303), «egualment» (C 1877, I50) per «igualment» (F 495), «mellor» (C 1877, I49) per «millor» (F 493), «octobre» (C 1877,26$)$ per «octubre» (F 303), ${ }^{4}$ i formes com «així» (C 1876 , I50), «decidida» (C I877, I50), «després» (pàssim), «juliol» (C I877, 26), «reyal» (C I878, I04) o «traslladat» (C I877, 26), per les més populars en el valencià de l'època «aixina» (F 503), «dicidida» (F 494), «demprés», «joliol» (F 304), «real» (F 324), «trasladat» (F 303), respectivament; en la mateixa línia substitueix el participi "complert» (C I878 IO6) per "complit» (F 325) i el pretèrit perfet «fou» (C I876, I50) per «fon» (F 502). També reemplaça alguns mots amb $i$ àtona per les variants corresponents amb $e$, que devia sentir com a més populars: "destinguit» (F 493), "previlejat» (F 494), «rediculiça» ( $\left.\mathrm{F}_{476}\right)$, «vesllum» (F 322) en comptes de «distinguit» ( $\mathrm{C}_{1877}$, I48), «privilejat» (C 1877, I50), «ridiculiça» (C I878, 23) i «visllum» (C I878, IO2), i també canvia sovint «ningun», «ningú» per «nengun», «nengú» (pàssim). Dona entrada a algun neologisme: «rewolver» (F 514) per «pistola» (C I876, I53). Corregeix la forma ultracorrecta «sudaren» (C I878, I06) en «suháren» (F 325). Reemplaça per $i$ algunes formes amb $e$ no registrades en altres fonts: «tureferari» (C I878, IO3) en «turiferari» (F 323), «llebreter» (C I878, IOI) en «llibreter» (F 320) i «lleteratures» (C I88I, I40) en «lliteratures» (F 338). Si no són errades, es podrien explicar fonèticament per assimilació, o, en el darrer cas, també per analogia amb lletra. La modificació també pot comportar l'ús d'alguns castellanismes: «siguient» (F 504) en lloc de "següent» (C I876, I52), "presionera» (F 322) en lloc de "presonera» (C 1878, 102), «reyne» (F 427) en comptes de «regne» (C 1879, 34), o «en busca de» (F 502) per «cercant» (C I876, I50).

Altres vegades, però, es decideix per formes que considera més cultes o més correctes en un registre formal, encara que puguen separar-se de les més habituals en valencià col-loquial: «infantesa» (F 493) i no «infantea» (C I877, I49), "puresa» (F 497) i no "purea» (C $1877, \mathrm{I} 53)$, a pesar que les segones van d'acord amb el valencià -ea (<-IॅTIA), «encarregada» (F 303) i no «encarregá» (C 1877, 26), «hómes» (F 300) i no «hòmens» (C 1877, 23), "premi» (F 504) i no "prémit» (C I876, I5I), «religiós» (F 30I) i no «relitjós» (C I877, 24), «doctor» (F 32I) i no «dotor» (C I878, IO2), «baptisme» (F 369) i no «batisme» (C 1879, I48), «volgut» (F 30I) i no «vullgut» (C 1877, 24), "col-loca» (F 496) i no "coloca» (C I877, I52), «col-laboració» (F 496) i no "colaboració» (C I877, I5I); algunes tenen un caràcter arcaic: «carchs» (F 302) en substitució de

4. En Escrig (185I) es registren només amador, igualment, millor i otubre, i respecte a dehembre, s'hi recull però com a entrada secundària de la principal decembre. 
JoAquim Martí Mestre

«cárrechs» ( $\mathrm{C}_{1877}$, 25), «emprenta» (F 319) per «impremta» (V i878, 100) o «argent» (F 346) per "plata» (C I88I, I49). ${ }^{5}$ També corregeix alguns castellanismes de la primera versió: «oblit» (F 504) i no «olvit» (C I876, I5I), «respectable» (F 494) i no «respetable» (C I877, I50), " «menysprehades» (F 514) i no "despreciades» (C I876, I53), «tanda» (F 496) i no «turno» (C I877, I5I), «almanachs» (F 496) i no "almanaques» (C I877, I52), «advocats» (F 427) i no «abogats» (C I879, 34), «els dos» (F 319) i no «entrambs» (C I878, I00), "se reflecta» (F 496) i no «se refleja» (C I877, I5I), "reduhí á céndra» (F 322) i no «reduhí á escombros» (C I878, IO2), encara que l'intent de correcció no sempre reïx, com quan substitueix «desarrollo» (C I879, 33) amb «desarroll» ( F 427). Valencianitza alguns noms propis, encara que els personatges no siguen valencians: «En Ferran Ossorio» (F 495) per «En Fernando Ossorio» (C I877, I5I), «Na Cárme Valparda» (F 478) per «Na Carmen Valparda» (C I878, 25).

Canvia la terminació -o d'alguns probables llatinismes per - $e$ : «alumno» (C I88I, I4I) en «alumne» (F 338), «teatro» (C I879, I49) en «teatre» (F 370) i «claustros» (C 1878, I02) en "claustres» (F 322). Però en altres possibles llatinismes amb -o no sempre actua en la mateixa direcció. Així, substitueix «sóci» ( $\mathrm{C}$ I877, 27) per «sócio» (F 304), però «ánimo» (C I878, 25) per «ánim» (F 478).

\section{CASTELLANISMESIRESTITUCIÓLITERÀRIADEVEUSTRADICIONALS}

Llombart, com altres escriptors renaixentistes, recupera per a la llengua literària nombroses veus tradicionals perdudes, envellides o que rebien la competència d'algun mot més modern, en la seua varietat lingüística, en aquest cas en valencià. En aquesta tasca, Llombart se serveix dels seus coneixements lingüístics, de lectures dels clàssics, de diccionaris, i de la coneixença que tenia dels autors contemporanis d'altres indrets del domini lingüístic, especialment de Catalunya.

En alguns casos el decandiment de la veu tradicional va unit a la competència d'algun castellanisme. ${ }^{7}$ Els autors renaixentistes s' esforçaren per reduir els castellanismes de la llengua literària, però aquest no era un procés facil, tenint en compte l'arrelament

5. Carch figurava en Ros (1739). El mateix Ros (I764: 24) recollia només argent, tot i que la situava entre les veus tradicionals que «el vulgo va olvidando», en benefici de plata, i en la Corrección de vozes (I77I) proposava corregir plata en argent.

6. Labèrnia (I839) i Escrig (I85I) donen prioritat a olvit sobre oblit, però Ros (I739) només recull oblit. En Escrig respetablement; en Labèrnia i el DCCL respectable. de la llengua.

7. Aquesta competència sovint no és exclusiva del valencià, sinó que ocorre també en altres varietats 66

Caplletra 69 (Tardor, 2020), p. 61-84 
d'alguns d'aquests mots en la llengua, tant en la col-loquial com en la literària, o el prestigi i el predomini social del castellà, els quals ocasionaven que molts dels mots de nova creació arribassen al català mediatitzats per aquesta llengua. Per això, i tenint en compte les circumstàncies socials del moment, a pesar de la tasca de depuració que Llombart dugué a terme, com els altres escriptors catalans del segle XIX, no pogué evitar la presència de castellanismes en la seua producció culta. ${ }^{8}$

Amb tot, sí que va saber recuperar algunes veus. Entre aquestes veus, es podrien diferenciar els casos en què en els textos populars de la segona meitat del segle XIX es manté el mot genuí, juntament amb el castellanisme, d'aquells en què en la producció de vocació popular de l'època pràcticament ja no es documenta el mot tradicional, la qual cosa, tenint en compte que els textos d'intenció popular generalment tracten de reflectir la llengua parlada, és indici d'un procés de substitució lingüística més avançat. Tant en un cas com en l'altre, Llombart fa servir el mot genuí en la seua obra culta.

En el primer grup tindríem mots com alé ( $\left.\mathrm{F}_{457}, \mathrm{C} 33\right)$, arracades ( $\left.\mathrm{C} 22\right)$, ase (F 63), baceta 'basseta' (F I49), bisbe ( $\mathrm{C} \mathrm{I}_{17}$ ), consol (F I22) i desconsol (F 309), enuig (C I878, 60), enutjat (id.), espectacle (F 246), fástich (C I875, 38), ${ }^{9}$ ferm, a (F 64, E 8), fixar ( $\mathrm{F}_{363}, \mathrm{C}_{38}$ ), guany (C 21), hoste (F 310), llabi (F 504), llavors (O I6, F 54), llest $(\mathrm{C} 25)$, nort $(\mathrm{R} 62)$, raig (F 262), ramat ( $\mathrm{C}$ I883, 42; $\mathrm{E}$ II), socós ( $\mathrm{R}$ I5), terratrémol (F 542), i en el segon: adéu ( $\mathrm{C}$ 1875, 62), alemany (F 528), almoyna (F 301), ${ }^{10}$ anyell (PV 393, 4I0), arquebisbe (F IOI), arquebisbal (F 80), arquebisbat (F 130 ), bisbat (F 130$)$, bresol ( $\mathrm{F}_{30} \mathrm{O}$ A 7), ceptre (F 239), deixeble ( $\mathrm{F}_{49}$ ), doll (F 313), enujós ( $\mathrm{C}_{1876}$, 30), ${ }^{11}$ faula (F 334), fel (PV 322) i fidel (C 31), illa (F 92), juhéu (F 213), lluyta (F 277), marbre (F III), palau (F 80), princep (F 29, C I8), roure (PV 397), sabi (E I8), sagell (F 263), sagellar (F 249), tenebres ( $\mathrm{PV} 403$ ).

No sempre, però, elimina del tot el barbarisme dels seus textos cultes. Així, absència (C 29) hi conviu amb ausencia ( $\mathrm{R}$ 39), alarb i arab (C I6) amb árabes (F 538), referits tots als musulmans que dominaren València, brodar (R Io, PV 393) amb bordar (R 50, C 24), cabdal (R 56, C 21, 22) amb caudal (F 527, PV 418), captiva (C I882, 2I) i cautiu (C I3), castellonench (PV 409) i castellonense (F 63I), cercar (F I04) i buscar (F 252), cobla (F 520) i copla (F 205), cognom (A 5, E I6), company (E 7) i companyero (F 3I) i en menor mesura companyer (F 134 ), comte ( $\mathrm{C}$ I878, I5) (compte $\mathrm{C} 22$ ) i conde (F 204), cristall (PV 395) i cristal ( $\mathrm{R} 50$ ), escriptor (F 32) i es-

8. Ell mateix n'era conscient, i en l'«aditament» de Los fills de la morta-viva lamentava «en la part del llenguaje» els «abundants castellanismes» del llibre (p. 762).

9. No trobem en l'obra culta de Llombart el castellanisme asco, però sí asqueroses (C I875, 6I).

Io. Dels autors populars valencians del segle XIX, només trobem almoyna en l'Ensisam, de Martí Gadea.

II. Però sí que apareix enutjar en alguns textos populars valencians de la segona meitat del segle XIX.

Caplletra 69 (Tardor, 2020), p. 61-84 
JoAquim Martí Mestre

El model lèxic culte de Constantí Llombart

critor (F 246), esglayar (A I4) i esglay (C 28) amb asustar ( $\mathrm{F}$ 308), esmeragda (F 299) i esmeralda ( $\left.\mathrm{C} \mathrm{I}_{1875}, 60\right)$, fera (C I6) i fiera ( $\left.\mathrm{PV} 4 \mathrm{13}\right)$, fruytes ( $\left.\mathrm{C}_{23}\right)$ i frutes ( $\left.\mathrm{PV} 427\right)$, llahor (F 44) i alabança (F 70), llinyage (F 80) i apellido (C 1876, I52), lloch (F 195), siti (F 2II) i puesto (F 72), mija-taronja (F I8I) i bóveda (F I48), oblidar (F 45) i olvidar (F 286), ombra (F 322) i sombra (F 280), ona (E 9) i ola (C 1875,60$)$, pertànyer (F 83) i pertenéixer ( $\mathrm{F}$ I2I), picament de mans ( $\mathrm{C}_{\mathrm{I} 876, \mathrm{I} 8)}$ i aplauso (F 54), racó (F $5 \mathrm{I}_{4}$ ) i rincó $\left(\mathrm{F}_{591}\right)$, refusar $\left(\mathrm{F}_{339}\right)$ i rejaçar $\left(\mathrm{F}_{508}\right)$, regidor $\left(\mathrm{F}_{42 \mathrm{I}}\right)$ i concejal $\left(\mathrm{F}_{310}\right)$, regne $\left(\mathrm{E}_{13}\right)$ i reine (F IOO), renda (F 526) i renta (F I09), repenedir-se ( $\mathrm{C}_{14}$ ) i arrepentir-se (A 22), sospitar (C 28) i sospejar ( $\mathrm{R}$ 54), surar (C 28) i flotar (C 1875, 85), trahit (PV 397) i traycionamvos (A I6), venjar (C 29) i vengar (A 24). També conviuen els verbs genuïns amb -re i -er amb els castellanismes moderns amb -ir: admétreri admitir, combatre i combatir, concebre i concebir, concórrer i concurrir, incloure i incluir, ometre i omitir, permetre i permitir. Apareix algun cas de $c a p(\mathrm{C} 26)$ però la forma predominant és el castellanisme adaptat quefe (F 208, C I882, 2I), i en menor mesura la forma no adaptada jefe (PV 4I6, 424). Igualment, rato (pàssim), amanéixer ( $\mathrm{F}$ 253), apoyar ( $\mathrm{F}$ 237) (i apoyo) i tio (F I86) són les formes habituals, i només trobem un cas d'estona (PV 335), rompre lo dia (F 253), recolsar ( $\mathrm{R}$ IO) i oncle (PV 375). En altres ocasions, en canvi, la presència dels castellanismes és només testimonial: loco apareix només una vegada en l'expressió tornar-se loco (F 299), la resta de casos usa els genuïns bóig (C I875, 48) i sobretot foll, folla (F 215, 30I, R 38), que forma derivats: follament (E IO), follia (F 5I4). Igualment, avi (F 29, C I875, II) és la forma habitual, també en femení àvia (PV 378) i en els derivats bisavi (F 677), bisavis (E I4), avior ( $\mathrm{C}_{42}$ ), i només trobem «agüeles joges» (F 475), en un cas, segurament motivat pel tema, els tipus populars caricaturitzats per Escalante. La forma habitual és també advocat, i rarament es troba algun cas d'abogat, avogat (C I879, I3), que, com hem vist en l'apartat anterior, el mateix Llombart tractava de corregir. Això sí, és més habitual en el derivat abogacia (F 316, 689, 694, 729), que coneix també la variant híbrida advogacia (F I26, I42, 38I, 42I), i no apareix el derivat genuí advocacia. Normalment apareix greu (E 8, F 156), i només trobem un cas de grave: «la veu grave»(C I875, 84), i el mateix es pot dir respecte al clar predomini de segle (pàssim) sobre sigle ( $\mathrm{R}_{32}$ ).

En la construcció de la llengua literària moderna Llombart no era partidari d'un model arcaïtzant, ${ }^{12}$ i pensava que les aportacions dels clàssics, sens dubte necessàries per a dignificar la llengua i lluitar contra els castellanismes superflus, havien d'estar

I2. Repassant les obres de Palanca i Roca, cita Lo guardià de Capugins, que, segons Llombart, «fon un ensaig escrit en masa arcaich llenguage llemosí, prematurament portat per alguns de nostres dramátichs al teatre» (F 470). 
mesurades per la realitat lingüística del moment. Així, tractà d'actuar de manera ponderada amb els mots antiquats, però sense renunciar a incorporar-n'hi alguns de forma selectiva. ${ }^{13}$

Així, doncs, va fer servir en la seua producció culta veus tradicionals que, a pesar de poder-se documentar en textos valencians antics, no eren habituals en l'ús dialectal valencià general de la segona meitat del segle XIX. Ja n'hem citat algunes que li serviren per contrarestar alguns castellanismes. Ara en veurem altres, que contribuïren a enriquir la seua llengua literària, però que, des del punt de vista del valencià general, es podien considerar arcaismes, encara que algunes s'utilitzen en la llengua parlada espontània en altres territoris del domini lingüístic: acunçar ( $\mathrm{C} 43)$, alcabaler ( $\mathrm{F}_{44}$ ), angoixa ( $\mathrm{R}_{37}$ ), angoixar ( $\left.\mathrm{C}_{\mathrm{I} 875}, 86\right),{ }^{14}$ aplech ( $\left.\mathrm{E}_{\mathrm{I} 7}\right)$, aseure ( $\left.\mathrm{C}_{\mathrm{I}} 879, \mathrm{I} 5\right)$ i seure (C I884, 68), aturar (PV 400), aucell (F 48), àvol (C 27), aydar (PV 388), benfactor (F I09), boscana (PV 374), cambra 'habitació, peça d'una casa' (A 7, PV 40I), catifa (E II), cimera 'plomall, ornament que coronava la part superior de l'elm dels cavallers' (C 38), clergue (R 54), cloure (C I878, 60), cobetjar (C I876, I4), coltellada (A I5), comés 'comesa' ( $\mathrm{F}$ 207), conquerir ( $\mathrm{F} 336)$, conqueridor ( $\mathrm{A}$ 33), convinent $(\mathrm{C}$ I876, I2, 16$)$, coratjós (C I4), deslliurar (C I882, 23), deturar (E 23, F I08), devallar (F 323, C 8), ${ }^{15}$ diada 'dia assenyalat' ( $\mathrm{C}_{19}$, PV 372), dida (F 212), ${ }^{16}$ empényer (PV 375), endreçar (E 7), enginy 'màquina de guerra' (A I4), enlluernar ( $\mathrm{C}$ I883, 39), esbalait (F 455), escuma ( $\mathrm{PV}$ 426), esdevenidor ( $\left.\mathrm{C}_{\mathrm{I}} 6\right)$, esguarts (C 8), esment ( $\left.\mathrm{C} \mathrm{I} 878, \mathrm{I} 6\right)$, esmentar (F 84), espahordir

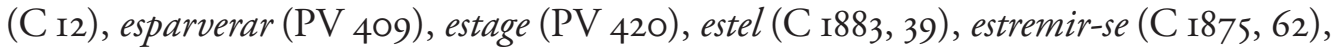
eynes (C 23), fada (C I883, 40), finar 'acabar' (PV 319), finir 'acabar' (O I6), 'morir' (C 1877, I6), flayres (C 1878, 59), flairós (C 1884, I29), flairors (C 33), fons (C 1876, 27), fontana (C I878, 59), garlanda (R 49), gay, a (C 4I, PV 373), grahó (F I59), hosts (C I882, 24), indret (PV 427), infant 'nen' (F 396), joliu (F 474), jorn (E I0), jòya 'gran alegria' (C I6), joyosos (C I884, 68), judici (E I2, F 75), llors (C I884, I30), malhaurat (F 340), malastruch, uga (R 2, PV 320), malfactor (F 228), malfadada (PV 403), mantell (C 34), mena 'classe' (F IOI), metcina 'verí' (C 27), mimbaren tr. (F IO7), amimvar

I3. La recuperació d'arcaismes era una pràctica prou habitual entre els autors renaixentistes. Vegeu, per exemple, Ginebra (2006), que estudia els arcaismes d'Àngel Guimerà.

I4. En els textos populars valencians del segle XIX amb aquest sentit es troba agonia i agoniar.

15. En El Mole figura com a forma alacantina, corresponent al valencià del cap i casal abaixar: «En Alacant á conte de dir abaixa, diuen deballa; als pimentons diuen pebreres; al trespol, trechinal [...]» (I84O, vol. I, p. I84-I85), i Escalante l'usava en boca d'una dona alcoiana per a caracteritzar el seu parlar com a diferent del de la capital: «Ya es michorn; deballe pronte» (Colección completa de las obras dramáticas, València, I894, vol. II, p. 667). I6. Llorente Falcó (200I: I, 309-3IO) comentava que al seu temps dida «en la capital [...] ha sido sustituída, desde hace ya algún tiempo, por el de "ama", en equivalencia de nodriza".

Caplletra 69 (Tardor, 2020), p. 61-84 
JoAquim Martí Mestre

intr. (F 532, 555), mimva: "Vostres noms, dels tirans afronte y mimva» (A I6), ministril (F 3IO), monestir (F 75), mot (E IO), negar-se 'inundar-se' (R 54), nin, a 'xiquet' (F 298, C I883, 4I), pagés (F 528), pech (E IO), perir (A 20), petit, a (E I5, F 47), plant 'plor' ( $\mathrm{F} 542)$, plaure $(\mathrm{C} 25)$, prear, prehar $(\mathrm{F} 350,627)$, prébere $(\mathrm{F} 71,96)$ i prévere $(\mathrm{C}$ 1884, 66), escrit per error amb accent, prohomania (C 23), realme (F 29), rebre (F I05), restar (F 55), sapiença (F 325), servar (M 30I), setje (F 300), sojornar (A 9), sotllevar 'sublevar' (C I882, 24), tardivol (E II), tempesta (PV 397), utilós (E I4), válua (R 48).

Igualment, enfront de formes com barri (PV 4I8), cadafal ( $\left.\mathrm{C}_{35}\right)$, cálçer ( $\mathrm{C}_{23}$ ), catiu (PV 385), conquesta (E I3), conquestador (E I8), conquestar (E I3), dubte (F 53) o dupte ( $\mathrm{O}_{14}$ ), dubtar (F 73), lluny (F 286), mellor ( $\left.\mathrm{C}_{1} 877, \mathrm{I}_{53}\right)$, nosaltres (E $\mathrm{E} 2$ ), vosaltres (A 2I), paradis ( $\mathrm{C} \mathrm{II} 84,68)$, quasi (F 30I), quotidiana (F 205), rector (F 32I), somni ( $\mathrm{R}$ 37), succehir (F 308), succés (F 309), vou 'veu' (C I884, 67), els textos valencians populars de l'època prefereixen altres variants formals més habituals en el valencià general de la segona meitat del segle XIx.

Algunes d'aquestes formes han tingut continuïtat en la llengua literària actual, però altres n'han quedat generalment excloses, pel seu caràcter arcaïtzant, com ara apellar 'designar amb un nom' (E I2, F 72), aymat, ada (C I877, 28), aymador (C I876, I3), aymants ( $\mathrm{C}$ 1876, 15$)$, aymia (PV 30), ${ }^{17}$ benavirat ( $\mathrm{M}$ 302) i malavirat ( $\left.\mathrm{F} 333\right)$, per benauirat i malauirat, cors 'cos' (F 309), deembre (C I877, 26), designe 'designi' (F 286), despenses 'despeses' (F 136), egual ( $\left.\mathrm{C}_{1} 878, \mathrm{I}_{2}\right)$, elet ( $\mathrm{C}_{36}$ ), emprentar ( $\mathrm{F}_{323}$ ), emprenta (F 706), escabell 'escambell' (C I875, 60), esvenidor 'esdevenidor' (C I883, I32), ${ }^{18}$ etat (F 326, E 9), fallir 'morir' (F 519), flum (R 37), hom 'home' (C 1878, 60), ignocent (C I876, 44), infadigable (C I875, I0), japeu 'xapeu' (C 34), judeus (PV 337), llansanger (C I876, 29), segurament forma errònia per lausanger; ${ }^{19}$ llau (F 87), llegenda 'lectura; acció i efecte de llegir' (F 51, 73), martre (C 23), maysó (C 7), menysprendre (PV 386), náugers $(\mathrm{F} 53),{ }^{20}$ per nauxer o nautxer, paternòsters 'rosaris' $\left(\mathrm{C}_{22}\right)$, pauruch $\left(\mathrm{R}_{37}\right)$, pris 'honor, estima' (PV 423), ${ }^{21}$ profon (R 48), sagrament 'jurament' (PV 399), seny 'senyal' (C 36), vigil 'vigilant' (C I2).

17. En Labèrnia i el DCCL.

I8. Sembla ser una reducció d'esdevenidor, que és la forma habitual en català medieval, a diferència d'esvenidor, que en el $D C V B$ només es documenta una vegada en Eiximenis. En canvi, els escriptors renaixentistes la usaren sovint. Per exemple, entre els valencians, a més de Llorente, es troba en Llombart, en Bodria i en Iranzo. I9. Amb palatalització de la $l$-inicial, d'acord amb la tendència catalana popular. Aquestes palatalitzacions són molt habituals en Llombart en els cultismes, ex. lliterari, llament, llímit, llírica, llocal, etc.

20. En el poema Lo peixcador d'Aguirre Matiol també accentuat en la primera sílllaba, náuger (Las Provincias. Almanaque para I884, p. I3I).

2I. Aquest sentit de pris es troba en Labèrnia (I839), i abans en el DCCL, però no en Ros ni Escrig, que recullen el mot pris però amb significats erronis ('primero', 'mañanita'). 


\section{VALENCIANISMES I FORMES COL·LOQUIALS}

D'acord amb la seua concepció de la llengua literària culta, Llombart incorpora en el seu «llemosí literari» formes lingüístiques procedents del valencià del seu temps, encara que no sempre tinguen una llarga tradició literària. Igualment, si el tema o el context ho afavoreix, no rebutja els mots i les unitats fraseològiques col-loquials. Pensava que una llengua de cultura no pot renunciar a les formes lèxiques i fraseològiques populars, que contribueixen a la seua riquesa i varietat, ja que entre les excel.lències que fan que una llengua adquiresca «la categoria d'idioma» es troba «son abundancia de paraules, termes y modismes» (F 30$)$.

Veurem primerament alguns dels valencianismes usats per Llombart. Cal advertir que no tots aquests mots i variants són exclusius del valencià, i que poden ser compartits per altres parlars, sobretot occidentals: abelloter 'arbre que fa bellotes' (F 533), el DCVB el registra en EscLl, abans figura en Escrig (I851); açucach (C 52), aforro 'estalvi' (F 668), alducar (PV 394), algeps (C 32), alifac 'xacra (de les persones i animals)' és un mot sobretot valencià (DECat, I, 196), en el text, per extensió, aplicat als defectes o imperfeccions d'una publicació: «axi es qu'encara que siguen molts enguany los alifáchs qu'es tróben en les planes de Lo Rat-Penat, confiem de veres qu'en los anys siguients millorará» (C I875, 9), altaria (F 685), amprar 'manllevar' (F 453), aplegar 'arribar' (F 310), atropoll (PV 387), bledana (C 1875, I2) i bledania (F I04), bresquiller (C I884, 64), camalets 'saragüells blancs de llenç' (F 50), carcallada (F 453), casilici (F I8I), variant formal de casalici, explicable per assimilació, corbella (PV 4IO), cútio 'quotidià, diari' (F 42I), castellanisme o aragonesisme, donyet (R 55), engonari (C 31 ), entabacar (F 215), entaulat (C I7), esguell (C I2, C 1875, 59), esvarar (F 159), fraures (PV 392), frontera 'façana' (R 56), gentola (A 9), grama 'gram' (C I883, 4I), ${ }^{22}$ justiprear (F 90), llampetja (C I878, 60), ${ }^{23}$ llaurador 'pagés' (F 265), llevantança (A 8), llimachs: «llargues llagunes plenes de llimachs» (F 3I), malaltós, osa (F 58I, 588), meló d'Aljer (F I80), meniu 'infant petit' (PV 380), ${ }^{24}$ picola (C 1876, 45), purnes (C 28), recialles $\left(\mathrm{O}_{13}\right)$, tarquim $\left(\mathrm{F}_{31}\right)$, teulahins $\left(\mathrm{C}_{1875}, 60\right)$.

Variants formals afavorides en valencià: adage (C I88o, II), agrunsar (F 279), Alamera (F 6I2), almánguena (F 138$)$, alvançat (F 364), arrails (F $18 \mathrm{I})$ i arrailar (C 1876, I6), asunt (F 75), avear (F 28I), colejal (F 277), coneiximent (F IOI) i naiximent (F 277), cresoleta (F 180), dénau (F 215), déset (F 453), desempellogar-se (C 28), variant

\footnotetext{
22. Segons el DCVB i el DECat (Iv, 607), és la forma nord-occidental, però és també la valenciana. 23. Balear i valencià, segons el $D C V B$.

24. El recull el $D C V B$ en $M G a d$, no es registra en el DECat ni en el DDLC.
}

Caplletra 69 (Tardor, 2020), p. 61-84 
JoAquim Martí Mestre

El model lèxic culte de Constantí Llombart

de desempallegar-se, la qual es troba en textos valencians dels segles XVIII, XIX i XX, dimats ( $\mathrm{R} 8$ ), dumenge (F II3), eixabuar 'aixovar' (F $\left.\mathrm{F}_{3}\right),{ }^{25}$ eixecució (F 260), eixecutar ( $\mathrm{R} 8)$, eixemple ( $\mathrm{F} 49)$, eixercicis ( $\mathrm{F} 237)$, eixércit ( $\mathrm{F} 323)$, encomençar ( $\mathrm{F} 78)$ i escomençar ( $\mathrm{F}$ 95), ensomi ( $\mathrm{R}$ 2), ensomiar (A 22), escapre ( $\mathrm{F}$ 53I), esgolar-se ( $\mathrm{F}$ 309), estomordit (C I6), estral (A 35), estrela (R 49), flamerada (A 36), gamell (R I5), gesmil (F 526), giner (F 74), inyor (F 630), joliol (F 99), llaujer (C 36) i allaugerar (F 319), máixqueres (C I875, 48), malmarrós ( $\mathrm{F}$ I74), mampéndrer (F 573), melengía ( $\mathrm{C}$ 1875, 84), mitant ( $\mathrm{A}$ 37) náufrech ( $\mathrm{R}_{38}$ ), núgol ( $\left.\mathrm{PV} 4 \mathrm{II}\right)$, obedir ( $\left.\mathrm{F} 55\right)$, orige ( $\left.\mathrm{F} 2 \mathrm{II}\right)$, ròtgle ( $\mathrm{C}_{36}$ ), taranyines ( $\left.\mathrm{E} \mathrm{I}_{4}\right)$. La tendència occidental a obrir la $e$ - de la síl.laba inicial explica les formes ancapotar (F 453) i anyorar (F 65).

Mots usats en sentit figurat, molts de caràcter col.loquial: ${ }^{26}$ aigua de corriola 'aigua de pou' (F 22I) (veg. DF), alitrencat 'malaltís, mancat de forces' (F I62), becada 'error comés per distracció, per irreflexió' (A 9), coent ("cohenta») 'persona ridícula per presumpció' (F 475), cordial 'vi' (A IO), dotor de secà (F 475), fums 'vanitat, presumpció, altivesa' (F 475), gorra: «amichs de gorra» (F 475), llunar 'defecte; condició vituperable d'una persona' (F 476), paixarell 'persona viva i astuta' (A Io), pardal 'home astut que obra en profit propi' (F 207), peixquera 'captura' (A I2), pelucones 'diners (en general)' (F 362), del castellà pelucona 'onza de oro', que, per extensió passà a aplicar-se, com en el text de Llombart, als diners en general, rabotada 'desaire, desatenció' (A I3), sobarbada 'censura, reprovació' (F 350), tronada 'gran manifestació d'irritació, de còlera' (F 274), xafar («jafá») 'superar, véncer' (F 5I). És molt menys habitual l'ús d'algun mot argòtic: jingar-se (d'algú) 'burlar-se'n' (per xingar) (C I876, I2), segons Coromines (DECat, Ix, 544), «mot gitano i caló».

Unitats fraseològiques. Per raons d'espai, seleccionem ara només els fraseologismes o les variants de fraseologismes no registrats en els diccionaris de referència $(D C V B$, $D F, P C C)$. De vegades, Llombart introdueix aquestes unitats amb expressions que en destaquen el caràcter popular i tradicional: «com á vegaes solem dirne» ( $\mathrm{C}$ i876, I3), «com solém dir» (F 323), «com sol dirse» (F 758), «com dia l'atre» (F 362), «com vulgarment solém dirho» (F 326), «diu l'adage valenciá» ( $\mathrm{R}_{2}$ ), «l'adatji diu» (C 1875 , 9), «que diuen los valencians» (F 207).

Locucions i concurrències: ${ }^{27}$ a dues per tres 'amb freqüència, sovint' ( $\left.\mathrm{F} 79\right)$, que sembla una ultracatalanització de la locució a dos per tres, l'única que consta en el

25. En el DECat (I, II5) no es registra aquesta forma en valencià, però sí eixahuar, eixaguar i aixauar. 26. Els mots col-loquials són més freqüents en Lo darrer agermanat, pel seu caràcter teatral.

27. Per a la diferència entre locucions i concurrències, vegeu Ginebra (2003). 
$D C V B$, apretar lo dogal al coll (a algú) (F 749), en el DCVB en plural, apretar (a algú) els dogals 'estrènyer-lo fort, fer-li molta pressió per obligar-lo a fer allò que no voldria'; en vies de fet 'en curs de realització' (C I879, I4), en el DCVB estar en via «estar encaminat, en curs de funcionament, en acció» a Santanyí; no deixar pedra per tocar (C 1876, I3), cf. no deixar pedra per moure (DCVB, PCC, VII, I2); no poder-se vindrer en coneiximent de la mare qu'els parí ( $\mathrm{F} 46)$, amb caràcter ponderatiu, cf. conéixer (algú) com la mare que el parí (DF); péndrer a la veu (un discurs, un sermó) 'transcriure'l, copiar-lo, conforme es diu' (F 452), plantar una berlandina (al llucero de l'alba) (o al cavall de Sant Marti) 'no acovardir-se davant ningú' (F 207), cf. dir quatre berlandines (a algui) «dir-li els quatre mots de la veritat, tirar-li a la cara», a València (DCVB); portar (una cosa) pels dits 'saber-la molt bé' (F 326), cf. saber (una cosa) per los dits o per tots los dits de les mans, saber o tenir (una cosa) pels caps dels dits (DCVB, DF); repartir-se llenya 'lluitar, guerrejar' (A I5), rompre la corda per lo fluix 'en un plet o disputa, ser castigada la part més feble' (F 320), cf. Sempre es trenca la corda per la part més flui$x a(D C V B)$; tirar la roba a l'aigua 'emprendre una actuació contundent i arriscada' (F 323), cf. tirar la roba a la mar (DF); treball de formiga 'treball feixuc i laboriós' (F 763), treballar com un lleó (F 395).

Comparacions elatives: estar fet un diable de lleig (A 27), cf. com un diable de lleig $(D F)$; fer més dany que una tronada (A I2), cf. tronada en DF; més viu que l'aire (F 48), ràpida com lo rellamp ( $\mathrm{PV} 4 \mathrm{IO})$, cf. anar com un rellamp (DCVB) i rellamp (DF).

Fórmules: allà vorem (C 1876, 13; C 1879, I4), indicant incertesa, respecte al futur, cos de Déu! (A Io), fórmula de jurament, cf. cap de Déu! (DF); raig de Déu! (A 8, 33).

Parèmies: Bon grapat son tres mosques (A I2), parèmia amb la qual es pondera que tota ajuda és bona, encara que a primera vista semble escassa o insignificant; $\mathrm{La}$ gent de Valencia, segons ho pren, s'ho deixa (C I880, II).

Variacions sobre fraseologismes: «Les tallades mira! No mira lo plat!» (C 24), variació de la unitat fraseològica Sembla que mira el plat i mira les tallades, que «es diu d'una persona que fa veure que atén a una cosa i posa més atenció a una altra» $(D C V B)$.

\section{MOTS PROCEDENTS D'ALTRES VARIETATS DIALECTALS DEL CATALÀ}

En el discurs inaugural de la societat Lo Rat Penat, Llombart es congratulava que el "crit patriotich de renaiximent donat fa temps per nostres germans de Catalunya» per fi arribava a València, i afirmava que els valencians havien d'imitar els "generosos esforços de nostres germans de Catalunya y les illes Mallorques» (E 9, II) en la tasca

Caplletra 69 (Tardor, 2020), p. 61-84 
JoAquim Martí Mestre

de recuperació literària i lingüística de la llengua comuna. Llombart veia com a pròpia la llengua dels catalans i dels mallorquins ${ }^{28}$ i, per això, trobava natural que els valencians, els quals, segons deia, s'havien incorporat més tard al moviment renaixentista, en la construcció de la llengua literària tinguessen en compte de manera selectiva les formes dels grans escriptors renaixentistes catalans. ${ }^{29}$

Per això, a partir d'aquests escriptors, i segurament tenint present també el diccionari de Labèrnia, ${ }^{30}$ Llombart va incorporar en la seua llengua literària culta diverses veus procedents del català d'altres regions, especialment de Catalunya, encara que històricament fossen alienes al valencià general. Són mots com els següents: *abrusar-se (PV 338), agradivol (F 253), *aixecar (E 9) i eixecar (F II4), *aixerides (PV 388), altivol, a (C 26, 42), bruncidores (C 36), bruyt (PV 397), *calabruixos (PV 391), *canalla 'mainada, conjunt d'infants' (F 215), *capficats (M 298), corsecar-se (C 26), *darrerenca (C I877, 28), dissort (E 8, F 86), enjoyellar 'enjoiar' (E II, F I05), ${ }^{31}$ *enlairar (R 9), esbadellar-se ( $\mathrm{PV}$ 402), esbatech ( $\mathrm{F}_{289}$ ), esperonar ( $\left.\mathrm{C}_{37}\right)$, festivol, a ( $\mathrm{O}_{4}, \mathrm{~F}_{476}$ ), *frisar (F 633, C 24), fuetejar (F 336), *gegantí, ina (A I4, PV 374), germanó (C I884, I32), * glatir (PV 379, 40I), * guspires (C 7), hostajar (F 529), *joguines (C I7), *llavoras (C I876, 30), ${ }^{32}$ llunyadà, ana (C I875, 59; F 72I), *llunyana (C I883, 40), malguanyat (F 259), *mirall (C 25), mijaner (A 32), *nen (F 644), *ovirar (C 16), *pató 'besada' (C I875, 60), *payral (C I876, I7), pensivols (C 35), *pertocar (C I876, 32), *poncella 'flor abans d'obrir-se' (R 37), preuada (F I44), prehuada (F 203, C 7), ${ }^{33}$ seguici (PV 428), *soroll (E 9), *tendrura (F 258), *terrabastall (PV 4I2), *tomballons (PV 4I3), *udols (M 303), veritable (F 476), els participis en -ert: * complert, a (F 75, 77), *ofert (F

28. En l'anuari Lo Rat Penat es poden trobar diferents declaracions de Llombart en aquest sentit. Per exemple, s'hi refereix a la Biblioteca catalana, de Marià Aguiló, «formada de les principals obres qu'en la nóstra llengua materna s'han escrit en lo Principat y en los antichs realmes de Mallorca y Valencia» (C I875, IO).

29. Un dels autors que Llombart més tingué en compte en la construcció del seu model lèxic culte fou el seu admirat Jacint Verdaguer. En la producció culta de Llombart es troben nombrosos mots, alguns dels quals no formen part del dialecte valencià del segle XIx, que es poden llegir en les tres obres de Verdaguer que Llombart citava en el seu poema A mossén Jacinto Verdaguer: Idilis y cants místichs, La Atlàntida i Canigó.

30. Guardiola (2005: 249) demostra que Llombart es va nodrir del diccionari de Labèrnia en la introducció en $E s c L l$ de mots procedents de Catalunya. Marquem amb $\left(^{*}\right)$ els mots de la nostra relació que es troben en Labèrnia.

3I. Probablement el tragué dels escriptors renaixentistes catalans, que l'usaven sovint; abans només es localitza en el Libre dels feyts d'armes de Catalunya $(D C V B)$. El primer autor valencià on trobem aquest mot és Llombart. No es troba en textos populars valencians del segle XIX.

32. En textos valencians sí que es troba llavores, però no llavoras.

33. Variant de prear. Segons el DECat (vi, 807), és una forma moderna, que documenta només en Verdaguer. I, encara que el $D C V B$, n'aporta també un exemple de mitjan segle xv, la gran majoria de documentacions les trobem a partir del segle XIX. 
Joaquim Martí Mestre

El model lèxic culte de Constantí Llombart

357), * rublert (V I35) i soferts (A 7), i variants formals com auba (C I875, 60), *aubada (C 1878, 59), esprit (F 278), *feyna (C 21), nigúls 'núvols' (R 37), *nuvi (PV 393), *ordre (F 75), *vetllar (C I882, 24) $\mathrm{i}^{*}$ desvetllar (F 474), i els derivats ordrenar (F I50), desordre (F 257) i desordrenats ( $\mathrm{F}$ 455), *papallona ( $\mathrm{C}$ 23), pauma ( $\mathrm{C}$ 24), pietós ( $\mathrm{C}$ 1884, 66), ${ }^{*}$ pler (C 16), *poltros (C 33), * ral (R 62).

\section{NEOLOGISMES I MOTS NO REGISTRATS}

Llombart, que considerava que la introducció de "veus nóves» contribuïa a restaurar i perfeccionar la llengua pròpia (F XIV), com altres escriptors renaixentistes, fa servir mots (o accepcions) creats durant el segle XIX, sovint per part dels mateixos autors renaixentistes, utilitzant recursos com el manlleu, el cultisme, la derivació, la composició o el canvi semàntic. Alguns d'aquests mots, accepcions o variants formals, avui dia són desusats, altres continuen en ús.

Vegem-ne alguns exemples: abim (PV 389), afiligranada (F I8I), afores (F 534), amorosench (PV 427), apegalis: «els parents apegalisos» (F 475), ${ }^{34}$ apreci (F Io8), ateneu (F 202), aticisme (F 484), bellugadiç (M 303), bufet 'despatx d'advocats' (F 339), carlisme (PV 4I4), catalaniste ( $\left.\mathrm{C}_{1877} \mathrm{I5}\right)$, consoci (F 423), cruent ( $\mathrm{PV}$ 398), debut (F 645) i debutar (F 75I), desenrastrar (E 9), ${ }^{35}$ desmarjat ( $\mathrm{C}$ I876, 44), per referència a un riu que ha ultrapassat els seus marges, ${ }^{36}$ despulls 'despulles' (F I62), dramátich 'dramaturg' (F 470), eixample 'ampliació d'una ciutat' (F 534), estança (M 30I), exànime (PV 397), febrosench (C 28), ferrocarril (F 52I), flamiger (M 30I), galanura (F 537), galicà (F I20), harém (C I884, I29), ignotes (PV 427), impremeditació ( $\mathrm{R} \mathrm{II}$ ), indisputable (F 265), lliberticida (C I4), llopada (PV 413), malversar (F 749), motriu (F 558), odorifich (F 526), parisien ( $\mathrm{F} 573$ ), parpre ( $\mathrm{C}_{24}$ ), parterre ( $\left.\mathrm{R} 49\right)$, penyascal ( $\mathrm{PV} 336$ ), póstum ( $\mathrm{F} 474)$, recomanable (F 47I), remoreig ( $\mathrm{PV} 4 \mathrm{IO})$, reps $(\mathrm{R} \mathrm{IO})$, resultancia $(\mathrm{F} 7 \mathrm{I} 2)$, revistar (F 534), rewólver ( $\mathrm{C}$ I876, I5I), sardóniques (F 722), solana 'sol molt fort, solellada' (A 8), temporer (F 638), tram-vies ( $\mathrm{R} 40)$, etc. I neologismes tècnics i científics: estalactita (C I884, 67), estereotipia (F 558), estereotipic (F 559), etimológich (F 724), fllólech (C 1876, 31), geodesia (F 758), gliptich (F 722), heliográfiques (C I879, 13), litografia (F 47I), numismàtica (F I08).

34. Mot no registrat en el DIEC, i no documentat en el DCVB ni en el DECat. El trobem en textos populars valencians del segle XIX i primer quart del xx.

35. En el CTILC es recull només en aquest text de Llombart; en el DECat (viI, 28I) sense documentació, en el $D C V B$ ni en $E s c L l$; abans es troba en Escrig (I85I).

36. En el DCVB desmarjar 'llevar els marges d'un camp', en Aladern i EscLl. Abans figura en Escrig (I85I).

Caplletra 69 (Tardor, 2020), p. 61-84 
JoAquim Martí Mestre

Entre les variants formals, n'hi ha de populars i de caràcter més culte, algunes artificioses. Les següents no solen aparéixer en els textos populars valencians de l'època: crudel (PV 398), ${ }^{37}$ dolcificar ( $\left.\mathrm{F}_{327}\right),{ }^{38}$ esculptor ( $\left.\mathrm{R} 55\right)$, faulós ( $\left.\mathrm{F}_{317}\right),{ }^{39}$ furent $\left(\mathrm{C}_{13}\right),{ }^{40}$ gimnasi (F 213), ${ }^{41}$ nutrir ( $\mathrm{R}_{64}$ ), reflet 'reflex' (M 302), superbis'superbs' (C 34$),{ }^{42}$ unánim (F 397) representa una ultracatalanització del llatinisme unànime. La forma cadavre (A 35, F I82) fou molt usada pels escriptors renaixentistes (veg. DECat, 38I-382), però els textos valencians populars del segle XIX prefereixen calavre.

Castellanismes documentats des del segle XIx. Entre els castellanismes lèxics dels textos cultes de Llombart es troben els que eren habituals en el valencià col-loquial del moment i els que devien tenir un caràcter literari o llibresc. ${ }^{43}$ Quant a la data d'aparició, es pot diferenciar entre els manlleus antics, generalment millor coneguts, i els documentats des del segle XIx, ${ }^{44}$ que són els que ara ocuparan la nostra atenció. Sovint, encara que no sempre, els castellanismes són adaptats a les característiques gràfiques i fonètiques del català. Marquem amb el signe $\left(^{\circ}\right)$ els mots que no solen trobar-se en els textos populars valencians de l'època, i amb $\left(^{*}\right)$ els no registrats en els diccionaris històrics ni descriptius de referència. ${ }^{45}$

'açabaig (C 24), 'acopio (F 79), acunyar (C I877, 13), "aforcar (A 22, 26), ajach (F I53) (cast. achaque), agijarrar (cast. achicharrar) (A 34), '* amoldar (C 58), 'arcediá (F 109), arrostrar (F 502), arrulls (R 37), 'atildat (F 235), bullanga (F I59) i bullanguer (F 204), 'bussó (PV 374) (cast. buzo), ${ }^{46}$ cabalgata (R 40) i ' cavalcata (C 33), que sembla

37. Forma ultracorrecta, segons el DECat (II, IO68).

38. Mot no registrat en els diccionaris històrics ni en el DDLC. Figura en Escrig (I85I).

39. Segons el DECat (III, 9I6), ultracatalanització de fabulós. Figura en Escrig (I85I).

40. En els textos populars valencians de l'època es troba furient, que és també l'única forma registrada en el $D C V B$, el DECat, el $D A g$ i Escrig (I85i).

4I. Es troba en Escrig (I85I) i, juntament amb gimnàs, en la segona edició del diccionari de Labèrnia (I864).

42. No registrat en el $D C V B$, el $D E C a t$ ni el $D A g$.

43. Amb tot, com diu Ginebra (2006: IIO-III) amb relació a Àngel Guimerà, a la llum dels coneixements actuals, sense una informació sistemàtica sobre la llengua de l'època, no sempre resulta senzill distingir els uns i els altres. En aquest sentit, potser ens podria ser d'alguna utilitat la comparació amb la llengua actual, tenint en compte els castellanismes que es mantenen en l'ús oral, i la comparació amb els textos del segle xix de vocació popular, que reflecteixen amb més proximitat la llengua parlada.

44. Entre aquests castellanismes recents, com diu Ginebra (2006), s'inclouen els castellanismes literaris que són fruit de «la voluntat de convertir durant el segle XIx el català en una llengua de cultura moderna», i en aquest cas el prestigi del castellà feia que no resultàs facil alliberar-se de la mediació d'aquesta llengua.

45. Ens referim al $D C V B$, el $D E C a t$, el $D A g$ i el $D D L C$.

46. Coromines (DECat, II, 35I) registra bussó en Labèrnia (I839) i l'interpreta com un error tipogràfic per busso. Cal dir que es repeteix en l'edició de i864. L'ús de bussó en Llombart podria suggerir que conegués aquest diccionari, o que fos més que un error tipogràfic. En Escrig (I85I) i EscLl, buç, i en MGad buç i buço. 
influïda pel genuí cavalcada, 'cabdill (A 22) i ** caudill (F 276), 'círcol'cercle' (C I875, 60; C 1879, I4), ${ }^{47}{ }^{\circ}$ códices (F I08), * complacient (F 580), 'datos (C 1875, I3), *dehesa ( $\mathrm{R}_{40}$ ), derribo (C 1882, 2I), derrotja (C I875, II), *dijarajero (F 229), ${ }^{*}$ escaparat (R $\left.3 \mathrm{I}\right),{ }^{48}$ '*estrejar «li estrejà la mà» (F 46I), ${ }^{49}{ }^{\circ}$ intajable (F 528), jarana (A I3), ${ }^{50}$ jarla (C I875, 60), 'jascarrillos (F 205), 'Ilant 'plor' (C 1875, 84), llindar 'limitar' (F 587), 'menudejar (R 8), mimbres (R 49), murmull (C I875, 60), " parques (R 54), ${ }^{\circ}$ valiós, a (F 64), etc.

Castellanismes registrats per primera vegada, i de vegades única, en Llombart: ajentes (F 288), '*almohadilles (F I8I), 'arrebolar (C I875, 6I), 'camp-sant 'cementiri' (F 310), ${ }^{51}{ }^{\circ *}$ carlino (C I875, II9), 52 ' columpiar-se (C I875, 60), '* costeig 'finançament' (F 47), ${ }^{* *}$ dominiquino 'dominicà (O I2), ${ }^{\circ *}$ esdrújuls (F II6), ${ }^{53}{ }^{\circ}$ partiqui (F 650), ${ }^{\circ}$ presionera (F 322), ${ }^{\circ *}$ vener subst. (C 1884, I31). L'ús de ${ }^{\circ *}$ cercle amb el sentit del cat. setge (A I2, F 276) deu ser un calc del castellà cerco, que sí que té aquest sentit. El mot ${ }^{\circ} *$ cum (R 37) (cast. cumbre) deu ser una ultracatalanització.

Alguns castellanismes amb anterioritat només els trobem en Escrig (I85I), d'on pogué extraure'ls Llombart: ${ }^{54}{ }^{\circ}$ cerch 'marc, límit que encercla un espai' (F 215, PV $322),{ }^{\circ *} \operatorname{dejat~(F~256)~(cast.~dechado),~}{ }^{\circ *}$ regodeig (C 17), ${ }^{\circ *}$ retoçones (F 560), ${ }^{*}$ roçadura $\left(\mathrm{O}_{7}\right)$, ${ }^{\circ}$ servidum (M 302 ), ${ }^{\circ *}$ mugrient (F I59), encara que mugre es troba ja en El Mole (I837), ${ }^{\circ *}$ padeiximents (F 257), si bé padeixements es documenta en el periòdic català La Llumanera (I880) (CTILC); ${ }^{* *}$ trins 'cants dels ocells, refilets' (PV 372) podria ser una adaptació del cast. trino (pl. trinos) o un postverbal de trinar. ${ }^{55}$

En alguns casos recollim en Llombart per primera vegada (i de vegades única) un mot, una accepció o una variant formal:

47. En el $D C V B$ es considera que ha arribat al català "per via del cast. circulo». En canvi, el DECat (II, $677)$ es limita a considerar-lo un "duplicat modern de cèrcol».

48. El DCVB, DECat, DAg i DDLC registren escaparata i escaparate, però no escaparat, que es troba també en altres textos valencians dels segles XIX i XX.

49. Cf. "un colse de casa, que ix estrechant el carreró» (Hernández Casajuana: El carreró de la llanda, València, I9I7, p. 3); estrejar figura en Escrig (185I).

50. També adaptat en carana (El Mole, I837, vol. II, p. 326).

5I. Deu ser una adaptació del castellà camposanto, que és, de fet, la primera forma que es documenta en català, al segle XIX (CTILC, DDLC). En castellà camposanto es troba ja al segle XIV (CORDE).

52. La forma habitual en els textos populars valencians de l'època és carliste.

53. En El Mole (I837) esdrújulos (CTILC).

54. Dos d'aquests mots, cerch i trins, també es troben en el diccionari de monosílllabs de Carles Ros, obra que en EscLl era considerada de parador desconegut.

55. En textos valencians de vocació popular del segle xix es troba la variant trini, pl. trinis. Segons el $D C E C H(\mathrm{v}, 633)$, trinar, d'origen onomatopeic, és castellà i portugués, però no català. En cast. trino es documenta al segle XVII $(C O R D E)$.

Caplletra 69 (Tardor, 2020), p. 61-84 
JoAquim Martí Mestre

El model lèxic culte de Constantí Llombart

a) Mots formats per derivació: *abundejar (O I5, F 257,394), ${ }^{56}$ d'abundaramb l'infix freqüentatiu -ej; *baldovinesch 'relatiu a Bernat i Baldoví' (F 488), *compositar 'compondre' (F 86, II7, 725), en el CTILC es documenta en Carles Salvador (1936), el trobem també en algun altre autor valencià de principis del segle Xx: «iVinga, no sigues tan foja! / y seguix compositant. / Tiran una á Catarroja. / ¿Qué te falta consonant?» (Ruiz Esteve: Formigueta d'or, València, I9ıo, p. 9), deu haver-se format a partir de noms de la mateixa família com compositor i composició; desagradivol (F IO5), *emposesar-se 'prendre possessió (en el text, d'un lloc)' (PV 420), figura en EscLli MGad; *ensaonar: "Ensahonats d'ells [dels col-loquis i romanços de Ros], escrigué l'impresor Escorihuela molts coloquis» (F 50), és a dir, influenciats pels escrits de Ros; el verb ensaonar, que, com assaonar, deu ser derivat de saó, no es registra en altres fonts; * envoltallar (PV 34I), derivat d'envoltar, *esparveriçada (C 27), *faldellina (C 24), *flándrurs 'flamencs, de Flandes' (F 318), format sobre l'antic Flandres 'Flandes', *folladura 'bogeria' (F 782; R 37), de foll, ${ }^{57}$ *inimitatiu 'inimitable' (F 5I), llemosinisme (C I878, I2), llemosinista 'renaixentista' ( $\mathrm{R}_{2}$ ), *malastrugat, ada 'malastruc, desgraciat': «La sort malastrugada» (PV 397), ${ }^{58}$ mariniste 'pintor de marines' (C I883, I25; R 31), *noument (C I882, 22), *prontana 'primerenca' (F 396, 474, 487, 597, 603), proveçalés: «fet en proveçalés» (F 44), derivat de Provença amb el sufix -és, que forma gentilicis, redolant, a: «les redolantes ones» (E 9), *tipistichs 'típics' (F 2IO), derivat de tipo o tip, amb el sufix -istic que, a partir de noms, forma adjectius amb el valor de 'relatiu a'; 'tirer 'persona que tira amb ballesta, ballester' (C 36), *tramesió 'tramesa' (F I64), valencianiste (F 509), *venerábil 'venerable' (F 84), vesllumar (F 526). Només els retrobem abans en Escrig (I85I): coajudar 'coadjuvar' (F 544), corderia 'establiment on es fabriquen o venen cordes' (F 209).

b) Formats per composició: *arábigo-valenciana (F 766), *artístic-lliterari (F 613), *caixa-banch (F 638) (entitat bancària), *cartó-tinta (F 559), * cientifico-recreatiu (F 534), *comparsa-cabalgata (R 40), *económico-filosófiques (F 669), *electrotipich (F 559), galvanoplastia (F 558), * geométrich-histórich (F 677), *llemosinovalencià (F 76I), *sacro-dramátich (F 772, 774), *satíricho-burlesques (C I876,

56. Marquem amb * els mots, variants formals o accepcions d'aquest apartat no registrats en els diccionaris històrics $(D C V B, D E C a t, D A g)$, descriptius (DDLC) ni normatius (DIEC, DNV).

57. Cf. «este desdeny á la llengua nativa [...] té remey, es curable com una malaltía, com un atra folladura cualsevol» (València Nova, València, I906, núm. II, p. 3).

58. En Escrig (I85I) figura el verb malestrugar com a sinònim de deshonrar. 
I52), sobreeixint 'sobreïxent' (F 484), *teatre-café (F 706, 75I), toponomástich (F 737).

c) Accepcions: *abjudicar (F 525, C 1880, I2), amb el sentit d'adjudicar, assignar', deu explicar-se per confusió de prefix entre adjudicar i abjudicar; ${ }^{*}$ cambriste 'membre d'una entitat oficial, d'una cambra' (F I87), ${ }^{*}$ espectació 'acte de veure com a espectador (una obra teatral)': "compartint-la ab la llectura de bons llibres y ab la espectació d'obres teatrals, a què.s sentia inclinat» ( $\left.\mathrm{F}_{3} 62\right)$, falliment 'defunció' (F I23), *falt subst. 'manca, falta' (C 1876, 16), *juhetes 'jueus' (C i882, 23), del mall. xueta, però aplicat, per extensió semàntica, als jueus en general; *periodístich subst. 'periodista' (F 32I, 530). L'ús de *diplomacia (F IO6) amb el sentit de 'diplomàtica' només el registrem abans en Escrig (I85I).

d) Manlleus de llengües diferents al castellà: bouquet 'ram petit de flors' (F 37I), en cursiva en el text, del francés, ${ }^{59}{ }^{*}$ felibrejada 'trobada o festa poètica dels poetes felibres' (F 398), de l'occità; *orfebrer (C 2I, 26), segons el DCVB i el $D E C a t(\mathrm{v}, 83)$, orfebre procedeix del fr. orfevre, i no es documentaria en català fins al Diccionari ortogràfic de Fabra (DECat), en EscLl figuren orfebre i orfebrer, sinònims d'argenter i plater. La terminació -er d'orfebrer cal entendre-la com analògica d'altres noms d'oficis formats amb aquest sufix, com els mateixos argenter $\mathrm{i}$ plater.

e) Variants formals: * aplopetich (F I5I), metàtesi, en Escalante aplopeixia i aplopeixiat; *baptejada 'batejada, acte de batejar' (F 3I), ${ }^{*}$ capitolació (F 7I8), * casolitat (O I6), *celestín: «celestín concert» (E 9), variant proclítica (com vin, bon); * coabjutor 'coadjutor' $\mathrm{i}^{*}$ coabjutoria (F 566), potser per equivalència acústica, códix (F 574), ${ }^{60}$ *cornocopia (A 7), *desemvolpament 'desenvolupament' (F 540), *enargullirse (F 613), derivat d'argull; *endecasilaus (F 227), * erudisim (F I87), *estableiment 'establiment' (F III), possiblement per encreuament amb els castellanismes estableiximent i establéixer, fatcina 'fascina' (C 1876, 32), ${ }^{61}{ }^{*}$ feluts 'fellons' (A 22, 39), terme ofensiu aplicat als nobles per part dels agermanats, homildosa 'humil' (F 28I), *indesputable (F 5OI), *inmarcehible 'immarcescible' (PV 376), proba-

59. No figura en el $D C V B$ ni en el $D E C a t$, i en el $D D L C$ no es documenta fins a I9Io, i amb aquest sentit en I9I6, com en el CTILC. Barri (270) registra bouquet 'pom de flors' en el rossellonés Saisset l'any i888. En cast. bouquet I92I (CORDE), en it. bouquet 'mazzo di fiori' I925 (DELI).

6o. No figura en el $D C V B$ ni el $D E C a t$, però sí en el $D D L C$, que el documenta en I9I9 en Martínez Ferrando, i en el CTILC des de I9I2. En el DECat (II, 796) es diu que el llatinisme còdex es va adoptar en el segle $\mathrm{xx}$, però ja es troba en el darrer quart del segle XIX (I882) (CTILC); la $i$ de còdix es podria explicar per influència de codi o còdic, o potser per códice, que també usava Llombart, i sembla un castellanisme.

6I. El DCVB arreplegà a Palma la pronunciació [fəssiná], del verb fascinar.

Caplletra 69 (Tardor, 2020), p. 61-84 
Joaquim Martí Mestre

El model lèxic culte de Constantí Llombart

blement per influència de marcir, *invilida 'envilida' (M 30I), per assimilació; *llicçoners 'lletsoner' (C 3I), derivat de la variant val. llicsó; * marevellosa (F 359), microscópic subst. 'microscopi' (F 86), *Miracre: «carrer del Miracre» (F I85), *occeani subst. 'oceà (PV 428), cf. Occeania (Labèrnia I839-40); *oregina 'origina' (A 38), ${ }^{*}$ peleografia (F I08), proeminent (F I56), *telescópichs subst. 'telescopis' (F 86), ${ }^{62}$ prohéçal: «nostres germans los prohéçals» (E IO), sense $n$, com proveçalés, que hem vist més amunt; ${ }^{*}$ revistirà 'revestirà (R 46), ${ }^{*}$ riligiós (F 539), ${ }^{*}$ sepolcre (C I876, I8), *vereficar («verefica») (F I13).

Apareixen abans en Escrig (I85I), d'on pogué extraure-les Llombart: engeni (F I22), variant del més habitual ingeni (pàssim); *entronch 'entroncament' (F II8), *fecúndia (F 469), variant de facúndia per encreuament amb fecund o fecunditat; indis 'índex' (F 72, 77), potser influït per indice, usada també per Llombart, o per assimilació a la í tònica; proscripte 'proscrit' ( $\mathrm{C} 1883,40)$, possiblement per influència de proscripció o proscriptor.

Algunes palatalitzacions de la $x$ en cultismes no les trobem en altres fonts: *eixajerat, ada (F 70, 298), *eixedí (F 462), *éixit 'èxit' (F 495 i pàssim). ${ }^{63}$

Semblen ultracatalanitzacions les variants formals *anagram (C I878, I08) ${ }^{64}$ i *pentégram 'pentagrama' (F 319), *coetà 'coetani' (F 215), *contemporans: «els seus contemporans» (F 286), * contemporánes: «les persones contemporánes» (F 3I), cf. contemporany (VN 19, 7; AV 42); *defect (PV 428), cf. defet (Fuster, 1827); *fetuts 'fetus' (A I4), *monosilau (F 49), monosilaus 'monosíl.lab' (F 352).

Són compartides amb Escrig (I85I): *amanuens (F I58, I76), *castrens 'castrense' (F 150), certam (C 20,33), falanig 'falange' (F 325) (Escrig falang), 'tips 'tipus' pl. (C I875, I5), cf. tip 'tipus' en Josep d'Orga (T 236).

\section{MOTS POPULARS}

A més dels que s'han comentat en apartats anteriors, en la llengua literària culta de Llombart hi ha molts mots populars, tant de documentació antiga com més recent. Alguns d'aquests mots actualment experimenten, almenys parcialment, un cert envelliment en valencià central, però a l'època sembla que eren bastant usuals: abraonar: «els abrahonen» (A 36), adobar-se: «los mals s'adóben» (C 1876, 45), aflamar: «lo cor aflama»

62. Cf. telescòpic (Llibret de la falla dels carrers de la Chordana y Burchasot, València, I9I8, p. 3).

63. En F 374 corregeix en «éxit» la forma «éixit» (C I879, I53).

64. En una segona versió del mateix text la canvia en «anagrama» (F 327). 
(A 14), aguaitar (C I878 59, C 25), albat (PV 378), alenar (F 333), amostrar 'ensenyar, instruir' ( $\mathrm{F}$ 323), antigalles (F 722), anyada «va seguir imprentant per algunes anyades» (F 321), argent viu (C 1878, 59), beceroles ( $\mathrm{F} 453)$, bocinet ( $\mathrm{F}$ 184), botiguer de salses (F 210), branca (F 382), bresca (E 20), brins (PV 394), brusent: «oli brusent» (A I4), calcigar (PV 4I2), capgirar (A I5, R 37), carrera 'carrers que formen l'itinerari d'una desfilada' (C I876, I50), centenar subst. 'centenari' (F 283, 382), conhort (A 33) i fer-se un conhort 'aconhortar-se' (PV 383), darrer, a (F 70, PV 417), desori (A 33), eixam 'gran quantitat (de persones)' (C $\mathrm{C}_{7}$ ), engolir ( $\mathrm{PV}$ 389), falaguer, a ( $\mathrm{F} 238$ ), fosar ( $\mathrm{F} 217$ ), jaure (F 299), llamp (C 1878, 60), llenç (C 13, F 107), mancar 'faltar' (F 369), nafrar (PV 388), nosa (F 55), poruga (C 28, PV 4IO), refugir 'defugir, procurar evitar' (F 428), rompre (E I4, F 310), solch (C I875, 62), tasca (F 662), trontollat 'atordit, confús' (E 7), etc.

\section{CLOENDA}

Constantí Llombart pretenia que tots els escriptors valencians se sentissen implicats en el moviment renaixentista, tant els cultes com els que conreaven una literatura més popular. Per això va assajar per a la llengua literària un model lingüístic de síntesi, que evitàs les formes considerades vulgars i castellanitzants de la llengua col-loquial, però també els arcaismes. Ara bé, mancats de referents lèxics fiables, eren normals els dubtes i les vacil-lacions entre els escriptors renaixentistes, i Llombart no en fou una excepció. De fet, quan tingué ocasió de reeditar algunes de les seues obres, hi va introduir canvis lèxics, i lingüístics en general, alguns només estilístics, però altres destinats a corregir algunes formes de la primera versió, pensant generalment en una llengua més actual i pròxima a la varietat valenciana, sempre dins d'allò que considerava uns paràmetres literaris de correcció.

En la depuració lèxica de la llengua literària, Llombart tingué en compte els clàssics i els escriptors renaixentistes de Catalunya, on creia que el moviment de recuperació cultural estava més consolidat que a València. En aquest sentit, un dels autors catalans que més influí en el model lèxic de Llombart fou Jacint Verdaguer. Igualment, va tenir presents les fonts lexicogràdiques, especialment els diccionaris de Carles Ros i de Josep Escrig, i segurament també el de Labèrnia.

El nostre autor es va proposar la recuperació literària de veus tradicionals, envellides o decadents, que rebien la competència de castellanismes. La riquesa lèxica ${ }^{65}$ era important en el model de llengua literària defensat per Llombart. Hi cabien les

65. Sobre el concepte de riquesa lèxica, vegeu Casanova (20II).

Caplletra 69 (Tardor, 2020), p. 61-84 
Joaquim Martí Mestre

El model lèxic culte de Constantí Llombart

veus tradicionals i els cultismes, però també el lèxic popular i dialectal, que facilitàs l'acostament als lectors valencians.

Igualment, partint de la unitat reconeguda de la llengua compartida amb catalans i mallorquins, Llombart enriqueix la seua llengua literària amb mots procedents d'altres varietats dialectals catalanes.

La combinació de la tradició i la modernitat és essencial en el model lèxic de Llombart, que va donar entrada a nombrosos mots introduïts en la llengua literària durant el segle XIX, formats valent-se dels recursos interns de la llengua (derivació, composició, desplaçaments semàntics) o del manlleu. De fet, comprovem que ell mateix crea algunes veus i és el primer a usar en la llengua literària diversos mots i variants formals.

JoAquim Martí Mestre

Universitat de València joaquin.marti@uv.es

ORCID o000-000I-5124-5225

\section{REFERÈNCIES BIBLIOGRÀFIQUES}

Blasco, R. (1985) ConstantíLlombarti «Lo Rat Penat», València, Diputació de València. Casanova, E. (20II) «La riquesa lèxica de l'obra valoriana», dins G. Lluch \& J. M. Baldaquí (eds.), Nova reflexió sobre l'obra d'Enric Valor, Alacant, Institut Interuniversitari de Filologia Valenciana, p. 55-73.

$C O R D E=$ Real Academia Española, Banco de datos (CORDE), Corpus diacrónico del español. [En línia: <http://www.rae.es>.]

CTILC = Corpus Textual Informatitzat de la Llengua Catalana, Barcelona, Institut d'Estudis Catalans. [En línia: <http://ctilc.iec.cat/>.]

$D A g=$ Diccionari Aguiló (1915-1934), Barcelona, Institut d'Estudis Catalans, 8 toms.

DCCL = Esteve, J., J. Belvitges \& A. Juglà (1803-I805) Diccionario catalán-castellanolatino, Barcelona, Tecla Pla.

DCECH = Coromines, J. (I980-I99I) Diccionario crítico etimológico castellano e hispánico, Madrid, Gredos, 6 vol.

DCVB = Alcover, A. M. \& F. de B. Moll (1988) Diccionari català-valencià-balear, Palma de Mallorca, Moll, io vol.

$D D L C=$ Diccionari descriptiu de la llengua catalana, Barcelona, Institut d'Estudis Catalans. [En línia: <http://dcc.iec.cat/ddlc/index.asp>.] 
DECat = Coromines, J. (1988-I99I) Diccionari etimologic i complementari de la llengua catalana, Barcelona, Curial, io vol.

DF = MarTí, J. (20I7) Diccionari de fraseologia (segles XVII-XXI), València, Publicacions de la Universitat de València.

DIEC = Diccionari de la llengua catalana (1995), Barcelona, Institut d'Estudis Catalans, 1995.

DNV = Acadèmia Valenciana de la Llengua, Diccionari normatiu valencià. [En línia: <http://www.avl.gva.es/dnv>.]

EscLl = EsCRIG, J. \& C. Llombart (I887) Diccionario valenciano-castellano, València, Pascual Aguilar.

Escrig, J. (I85I) Diccionario valenciano-castellano, València, J. Ferrer de Orga.

Estrela, J. E. (20r8) Constantí Llombart, València, Institució Alfons el Magnànim.

Fuster, J. P. (I827) Breve vocabulario valenciano-castellano sacado de varios autores, València, José Gimeno.

Ginebra, J. (2003) «Fraseologia, concurrències lèxiques i llengua estàndard», dins M. À. Pradilla (ed.), Identitat lingüistica i estandardització, Valls, Cossetània, p. 8-55. — (2006) «Sobre el lèxic de l'obra teatral d'Àngel Guimerà», dins J. Massot i Muntaner (ed.), Estudis de Llengua i Literatura Catalanes, LIII, Barcelona, Publicacions de l'Abadia de Montserrat, p. IO3-I2I.

Guardiola i SaVall, M. I. (2005) «L'aportació de Llombart al diccionari d'Escrig», dins V. J. Escartí \& R. Roca (eds.), Constantí Llombart i el seu temps, València, Acadèmia Valenciana de la Llengua, p. 233-255.

Labèrnia, P. (1839-40) Diccionari de la llengua catalana ab la correspondència castellana y llatina, Barcelona, Espasa Germans, 2 vol. (2a ed. 1864-65).

Llorente Falcó, T. (200I) Memorias de un setentón, València, Federico Doménech.

MarTí, J. (2005) "Constantí Llombart i la llengua», dins V. J. Escartí \& R. Roca (eds.), Constantí Llombart i el seu temps, València, Acadèmia Valenciana de la Llengua, p. 2OI-23I.

MGad = Martí I GADEA, J. (I89I) Diccionario valenciano-castellano, València, José Canales Romà.

PCC = FARnÉs, S. (1992-1999) Paremiologia catalana comparada, Barcelona, Columna, 8 vol.

Roca Ricart, R. (2007) Teodor Llorente i la Renaixença valenciana, València, Institució Alfons el Magnànim.

Ros, C. (1739) Breve diccionario valenciano-castellano, València, Joseph García.

- (1764) Diccionario valenciano-castellano, València, Benito Monfort.

- (177I) Corrección de vozes y phrases, València, Francisco Burguete. 
JoAquim Martí Mestre

El model lèxic culte de Constantí Llombart

- (2004) Ràro diccionàrio valenciàno-castellano, ùnico, y singulàr, de vòzes monosylabas, estudi introductori i edició de Maria Isabel Guardiola i Savall, Alacant, Universitat d'Alacant.

Obres de Constantí Llombart citades:

$\mathrm{A}=$ Lo darrer agermanat, València, Emili Pasqual, I882.

$\mathrm{C}=$ La copa d'argent, València, Joseph Ortega, 1887.

$\mathrm{C}(+$ any $)=$ Lo Rat Penat. Calendari llemosi, València, Pasqual Aguilar, I874-I883.

$\mathrm{E}=$ Excel.lències de la llengua llemosina. Discurs panegírich llegit en la solemne sesió inangurativa de Lo Rat-Penat, València, Emili Pasqual, I878.

$\mathrm{F}=$ Los fills de la morta-viva, València, Pasqual Aguilar, I883.

$\mathrm{M}=$ «La mort del conqueridor. Llegenda del segle XIII. Lúltima victòria», La Renaixensa, 37-40 (1888), p. 297-304.

$\mathrm{O}=$ Obres festives ab lo tractat del pet compostes, segons antiga, generaly molt rahonable tradició, pel pare Francesch Mulet, València, Francesch Aguilar, 1876.

$\mathrm{PV}=$ Poesies valencianes, introducció $\mathrm{i}$ edició a cura de Rafael Roca, València, Acadèmia Valenciana de la Llengua, 2006.

$\mathrm{R}=$ Lo Rat-Penat. Periòdich lliterari quincenal, València, Unió tipogràłica, I884-I885 (ed. facsímil en Blasco, 1985).

$\mathrm{T}=$ Tipos d'auca, València, Manuel Vilar, 1878. 